\title{
Effect of anti-hail nets with different colors on 'Eva' apple trees agronomical responses
}

\author{
Marília Aparecida Stroka ${ }^{1}$, Ricardo Antonio Ayub ${ }^{2}$, Daurimar Mendes da Silva ${ }^{3}$, \\ Isabela Letícia Pessenti ${ }^{4}$, André Belmont Pereira ${ }^{5}$, Eduardo Augusto Agnellos Barbosa ${ }^{6}$
}

\begin{abstract}
The aim of the current research was to evaluate the impact of 'Eva' apple tress cultivation under nets with different colors as opposed to cultivation deprived of net treatment on the attributes related to the vigor of the plant, production and fruit quality. The evaluations were carried out during the 2017/18 and 2018/19 crop growing seasons at commercial production fields located in the municipality of Porto Amazonas, PR. The treatments in study consisted of a control (plants grown with no protecting net), along with plants protected by anti-hail nets of distinct colors such as white, crystal (transparent) and black. The following response variables were assessed herein: length and diameter of the branch, plant height and branch diameter as plant vigor measurements, crop production $\left(\mathrm{kg} \mathrm{plant}^{-1}\right)$ and yield $\left(\mathrm{kg} \mathrm{ha}^{-1}\right)$, and number of fruits per plant as to productive yield of the cropping system, as well as shape (height and diameter) of the fruits, mass, Hue angle, firmness, soluble solids and titratable acidity to test grade or fruit quality. There was no significant effect of protecting nets on both vigor and development of the plants. However, production and yield were consistently more expressive under crystal and white protecting nets throughout the second crop growing season. This demonstrated that 'Eva' apple trees were conducive to render as well as or even better than those plants bereft of protecting nets in view of the fact that the former treatments caused the plants to suffer less harmful impacts promoted by hail events, excess of wind, and sun burning disorders. The black anti-hail net resulted in negative outcomes as to coloration of the fruits in conjunction with titratable acidity, making them reddish and acidic and, therefore, less attractive for in natura commercial consumption.
\end{abstract}

Index Terms: Fruit quality, plant growth, photo-selective net.

\section{Efeito de telas antigranizo de diferentes colorações sobre as respostas agronômicas de macieiras 'Eva'}

Corresponding author: rayub@uepg.br

Received: December 07, 2020 Accepted: March 12, 2021

Copyright: All the contents of this journal, except where otherwise noted, is licensed under a Creative Commons Attribution License.

\section{(cc) EY}

Resumo - Este trabalho objetivou avaliar a interferência do cultivo de macieiras 'Eva' sob tela anti-granizo de diferentes cores, em comparação com o cultivo em pleno sol, sobre os atributos relativos ao vigor da planta, à produção e à qualidade de frutos. As avaliações foram realizadas durante as safras de 2017/2018 e 2018/2019 em pomar comercial localizado no município de Porto Amazonas-PR, Brasil. Os tratamentos consistiram em um controle (plantas sem cobertura) e plantas cobertas com telas antigranizo, nas cores branca, cristal (transparente) e preta. As variáveis avaliadas foram as seguintes: comprimento e diâmetro de ramo, altura da planta e diâmetro de tronco, tomadas para medidas de vigor da planta, bem como produção $\left(\mathrm{kg} \mathrm{planta}^{-1}\right)$, produtividade $\left(\mathrm{kg} \mathrm{ha}^{-1}\right)$ e número de frutos por planta, com vistas à caracterização do rendimento biológico da espécie cultivada, e ainda forma (altura e diâmetro) dos frutos, massa, ângulo Hue, firmeza, sólidos solúveis e acidez titulável, para atestar a qualidade da fruta. Constatou-se que não ocorreram diferença de vigor e desenvolvimento da planta sob telados, em comparação com o cultivo sem tela de proteção. No entanto, a produção e a produtividade foram mais expressivas sob as telas cristal e branca, durante a segunda safra, demonstrando que a cultivar Eva pode produzir tão bem ou melhor que quando cultivada a céu aberto, mantendo-se as plantas mais protegidas de riscos climáticos relativos, como granizo, vento excessivo e queimadura de sol. A tela protetora na cor preta proporcionou impactos negativos sobre a coloração de frutos e a acidez titulável, tornando os frutos menos vermelhos e ácidos e, portanto, menos atraentes para consumo in natura.

Termos para indexação: Qualidade da fruta, crescimento de planta, tela fotoseletiva.

\footnotetext{
${ }^{1}$ Agronomist, Master's Degree Student, State University of Ponta Grossa, Ponta Grossa-PR, Brazil. E-mail: mariliastroka.agro@hotmail.com ${ }^{\text {(oRcid: }}$ $000-0002-528$

${ }^{2}$ Agronomist, PhD, State University of Ponta Grossa, Ponta Grossa-PR, Brazil. E-mail: rayub@uepg.br(0RCID 0000-0003-3240-8417)

${ }^{3}$ Agronomist, PhD, State University of Ponta Grossa, Ponta Grossa-PR, Brazil. E-mail: daurims@gmail.com (0RCID 0000-0002-0364-2442)

${ }^{4}$ Agronomist, MSc, State University of Ponta Grossa, Ponta Grossa-PR, Brazil. E-mail: isabelaleticiapessenti@gmail.com ${ }^{\text {(oRcid } 0000-0002-}$ 5176-3134)

${ }^{5}$ Agronomist, PhD, State University of Ponta Grossa, Ponta Grossa-PR, Brazil. E-mail: abelmont@uepg.br(0RCID 0000-0002-1673-9841)

${ }^{6}$ Agronomist, PhD, State University of Ponta Grossa, Ponta Grossa-PR, Brazil. E-mail: eduardo.agnellos@gmail.com ${ }^{(0 R C I D}$ : 0000-0002-1393-4166
} 


\section{Introduction}

The cultivation of apple trees (Malus domestica Borkh) promotes remarkable bursts either in national or international agrobusiness, since it favors growth of municipalities all over the world in such a fashion as to generate jobs and substantial incomes. The world apple tree productions reached the mark of 86.1 million of tons of fruits in 2018, from 4.9 million hectares harvested, where as in Brazil particularly at Southern region productions soared to roughly 1.2 million of tons from 33 million hectares harvested (FAO, 2020).

Among the challenges featuring apple tree production systems, the need of delivering fruits with good quality and appearance to the rural growers in the face of biotic and abiotic factors conditioning yield in an economically feasible way in view of sustainable agriculture deserves special attention from a research perspective. Especially in the southern region of Brazil, where the State of Paraná is located, destructive hailstorms are frequently observed, with higher incidence in the months of September to November, leading to risks of loss on quality and yield for apple tree cultivation (MARTINS et al., 2016; PORSCH et al., 2018; CALDANA et al., 2019).

One of the current alternatives to be adopted in apple tree orchards lies in the usage of protecting nets with different colors, which possess a photo-selective action and in turn prevents injuries caused by hail events (MANJA and AOUN, 2019). Apart from a conspicuous anti-hail function, such protecting nets might play a role in mitigating the impacts promoted by excess of wind and heat at a given specific-site, reduce physiological disturbs due to sun burning exposures, increase yield uniformity and also guarantee rentability plus profitability at commercial apple tree orchards (MANJA and AOUN, 2019; SERVER et al., 2020).

Nevertheless, a number of scientific investigations have been reporting changes in microclimate of apple tree orchards whenever protecting nets were employed, mainly as a function of significant reductions in fractions of photosynthetically active radiation flux densities, with effects ranging from the influence of morphophysiological characteristics of the apple variety, location of production fields, color, material structure and net spectrum taken into consideration. This poses questions and doubts concerning the possibility of protecting nets to trigger damages to cultivation and fruit quality expression at different environmental conditions (TREDER et al., 2016; MANJA and AOUN, 2019; SEVER et al., 2020).
In Brazil the main apple varieties cultivated at a large scale are to be 'Gala' and 'Fuji', mainly for the regions of temperate climates, whereas consumers little by little have their minds open to the introduction of new genotypes far more adaptable to regions with fewer cold hours patterns (BERNARDI et al., 2004). The Agronomic Institute of Paraná (IAPAR) selected Eva cultivar in the 1979 breeding program from the crossing between 'Anna' and 'Gala' cultivars, pointing out that such a genetic material was considered to demand a less amount of chilling requirements (ranging from 330 to 350 unities of cold hours) and also to be an option for tropical regions and under environmental conditions unsuitable to the development of other genotypes (HAUAGGE and TSUNETA, 1999; HILGENBERG and AYUB, 2014). The 'Eva' fruits showed good quality, sweet, possess a balanced acidity, precocity and considerable resistance to diseases excelling yields at production fields located in Paraná, Minas Gerais and Northeast of Brazil (HAUAGGE e TSUNETA, 1999; OLIVEIRA et al., 2011; LOPES et al., 2012). However, there is no scientific evidence describing the performance of such a genotype grown under protecting net conditions. In light of such a gap in research, this study aimed to evaluate the impacts of protecting nets with different colors (black, white and crystal clear color) compared to no screen treatment (control) on the agronomical responses of Eva cultivar expressed by crop aspects related to plant growth, yield and fruit quality in the region of Campos Gerais do Paraná, Brazil.

\section{Material and methods}

A field experiment was carried out throughout 2017/2018 and 2018/2019 crop growing seasons at a commercial apple tree orchard located in the municipality of Porto Amazonas, PR, Brazil (25 $5^{\circ} 34^{\prime}$ latitude South; $49^{\circ} 57^{\prime}$ longitude West; $838 \mathrm{~m}$ altitude). According to the Köppen-Geiger classification, the climate is supposed to be $\mathrm{Cfb}$ (APARECIDO et al., 2016). Sum of rainfall (mm), average air temperature $\left({ }^{\circ} \mathrm{C}\right)$ and global radiation (W $\mathrm{m}^{-2}$ ) data during the experiment period were collected by Santa Catarina Agricultural Research and Rural Extension Company (EPAGRI) from a weather station, located in the municipality of Porto Amazonas, PR (Figure 1A, 1B and 1C) (EPAGRI, 2020). 


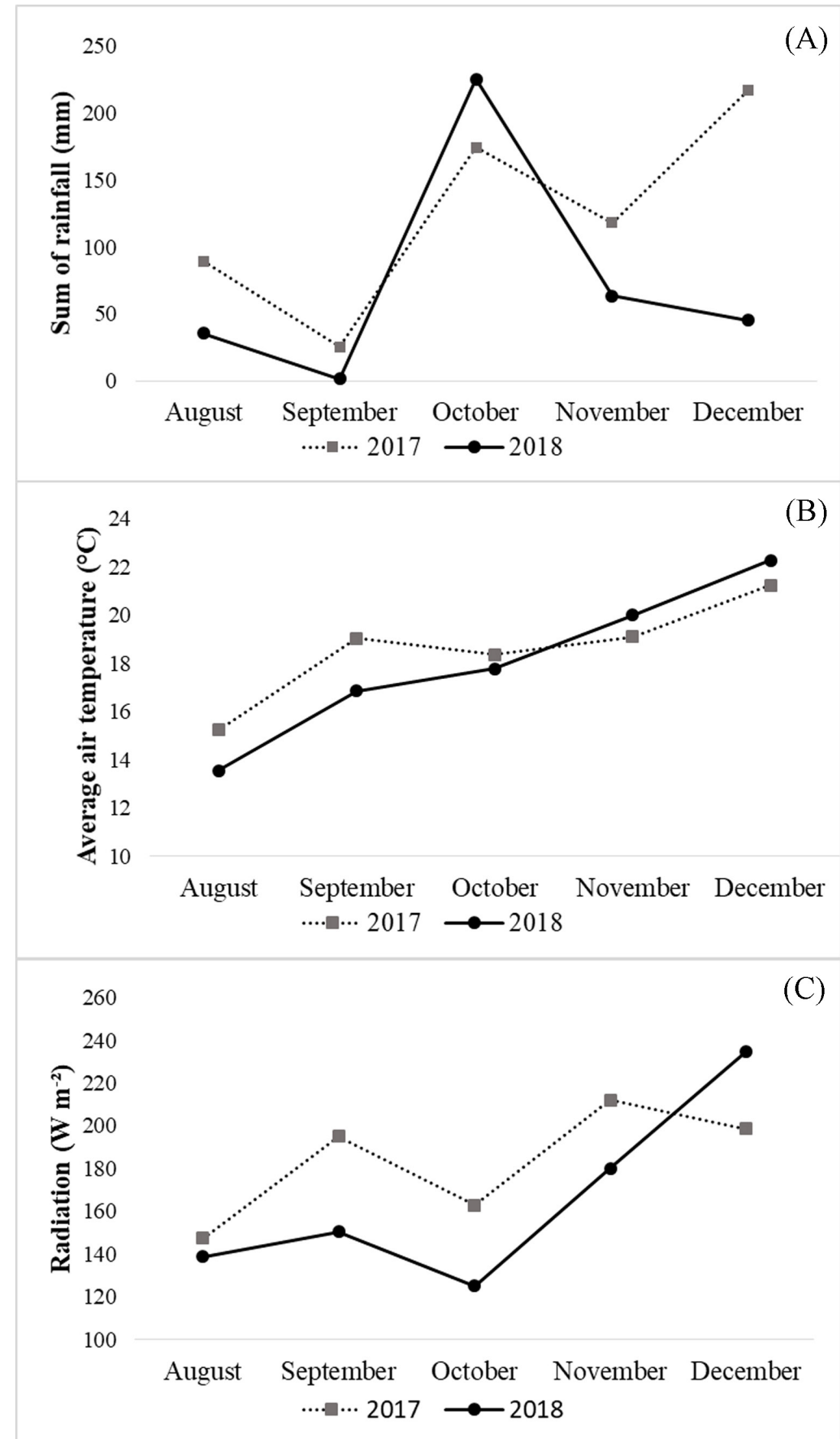

Figure 1. Regime of rainfall overall ( $\mathrm{mm})$, monthly mean air temperature $(\mathrm{oC})$ and global solar radiation flux density (W m-2) monitored by an automatic weather station belonging to EPAMIG in the municipality of Porto Amazonas, PR, Brazil. Source: EPAMIG (2020). 
'Eva' apple trees grafted onto 'Maruba' as a rootstock and 'M9' as an interstem filter were taken into account at our field experiment in view of Princesa cultivar as a pollinizer at a ratio 7:1, at four years-old of physiological age under the tall spindle planting system. In both growing seasons, comprising April through June, pruning and trunk strangulation were performed with the purpose of stimulating bud's dormancy breaking. Even using the cultivar Eva, which is less demanding in terms of the number of hours of cold, it is recommended to break dormancy to uniformize the sprout and make flowering compatible for this cultivar (CRUZ JUNIOR and AYUB, 2002). To this end, $0.8 \%$ hydrogenated cyanamide along with $3 \%$ mineral oil was applied whenever swollen buds were visible in the field.For the chemical thinning, applications with 90 grams per hectare of benzyladenine growth regulator during both growing seasons were taken into consideration in order to cause the fruits to reach the size of $12-\mathrm{mm}$ diameter along with flowers with low quality so that final load of fruits with 1 to 3 fruits per bud might have been achieved.

The treatments adopted in the current study comprised one control treatment featured by plants deprived of covering nets in conjunction with apple trees covered by anti-hail protecting nets with three different colors, such as white (2x6-mm sieve mesh), crystal (transparent, $3 \times 7-\mathrm{mm}$ sieve mesh) and black $(2 \times 5-\mathrm{mm}$ sieve mesh) as illustrated in Figure 2. Plants disposed under such distinct nets remained covered and protected throughout the entire crop cycle of the apple trees in the experimental area. Protecting nets were set up at the first crop growing season along the main planting line in the face of two water format at a distance between rows of $20-30 \mathrm{~cm}$ to promote hail run-off out of between cultivation lines, following leveled cultivation orientation. All of the protecting nets had dimensions of $0.30-\mathrm{mm}$ thickness by means of weaving ranging only from composition and coloration.

The field experiment itself was split into analyses of plant growth, yield and fruit quality. Plant vigor were assessed by branch diameter $(\mathrm{BD}, \mathrm{mm})$ and branch length $(\mathrm{BL}, \mathrm{mm})$, gauged on two branches horizontally disposed at the medium height of crop canopy; plant height $(\mathrm{PH}, \mathrm{mm})$ measured from soil surface up to the tip of the highest branch of the plant; and trunk diameter (TD, $\mathrm{mm}$ ) by means of a pachymeter at $15-\mathrm{cm}$ high above soil surface. At manually harvest, fruits in commercial maturation stage were counted and weighted to determinate production $\left(\mathrm{kg} \mathrm{plant}^{-1}\right)$, number of fruit per plant (NFP) and yield $\left(\mathrm{kg} \mathrm{ha}^{-1}\right)$.
With regards to analyses dealing with post-harvest and determination of fruit quality, apple fruits were transported to the laboratory and stored in a frigorific chamber for a period lesser than 10 days until biometric and chemical analyses on the fruits were made. For each single apple fruit, the following physical variables were scrutinized: fruit mass $(\mathrm{g})$ by means of a precision scale, fruit diameter $(\mathrm{mm})$, plant height $(\mathrm{mm})$ through a digital pachymeter positioned through equatorial and longitudinal lines of each fruit, respectively; superficial coloration of epidermis with the use of a Minolta colorimeter model Croma meter CR-400/410, seeking $\mathrm{L}^{*} \mathrm{a} * \mathrm{~b}$ parameters for the calculation of Hue angle $(\mathrm{H})$ from the equations as follows: $\mathrm{H}=\tan \left(\mathrm{b}^{*} / \mathrm{a}^{*}\right)$ when $\mathrm{a}^{*}>$ 0 and $\mathrm{b}^{*}>0$ or as $\mathrm{H}=180^{\circ}-\tan \left(\mathrm{b}^{*} / \mathrm{a}^{*}\right)$ when $\mathrm{a}^{*}<0 \mathrm{e} \mathrm{b}^{*}$ $>0$, since angle $0^{\circ}$ depicts pure red color, $90^{\circ}$ represents yellow, $180^{\circ}$ green, and $270^{\circ}$ blue (LANCASTER et al., 1997); and finally pulp firmness (N) by means of a digital penetrometer with an $11 \mathrm{~mm}$ tip positioned at the portion of the fruit with the largest diameter by the removal of the epidermis from the locus.

Chemical variables were evaluated by quantification of total soluble solids ( $\mathrm{SS}-{ }^{\circ} \mathrm{Brix}$ ) using a portable refractometer DIGIT model 103 along with titratable acidity (TA) in compliance with AOAC (2007), expressed in grams of malic acid per $100 \mathrm{~mL}$ of apple juice. Moreover, ratio defining the quotient between SS and TA proposed in order to examine aptitude of in natura consumption or industrial use was calculated.

The field experiment itself was split into analyses of vigor, plant development, yield and fruit quality. As to plant vigor, the following response variables were assessed: branch diameter $(\mathrm{BD}, \mathrm{mm})$ and branch length $(\mathrm{BL}, \mathrm{mm})$ gauged on two branches horizontally disposed at the medium height of crop canopy, plant height $(\mathrm{PH}, \mathrm{mm})$ measured from soil surface up to the tip of the highest branch of the plant, and trunk diameter (TD, $\mathrm{mm}$ ) by means of a pachymeter at $15-\mathrm{cm}$ high above soil surface. For manual harvesting, fruits at commercial maturation stage were counted and weighted to determine production $\left(\mathrm{kg} \mathrm{plant}^{-1}\right)$, number of fruits per plant (NFP) and yield $\left(\mathrm{kg} \mathrm{ha}^{-1}\right)$ 
The experimental data collected from apple tree orchards were subjected to statistical analyses by means of a computational system RStudio (R CORE TEAM, 2019), package ExpDes, with the aim of verifying normality of the data by the Shapiro-Wilk Test at a 5\% reliability and, whenever necessary, technique of data transformations was adopted prior to the analysis of variance (ANOVA) $(\mathrm{p}>0.05)$ to check veracity of both scientific and statistical hypotheses proposed herein. In order to quantify the effect of the factors on response variables scrutinized, the Tukey Test was applied with the main purpose of identifying significant differences among treatments at a $5 \%$ probability on the basis of multiple comparisons approach.
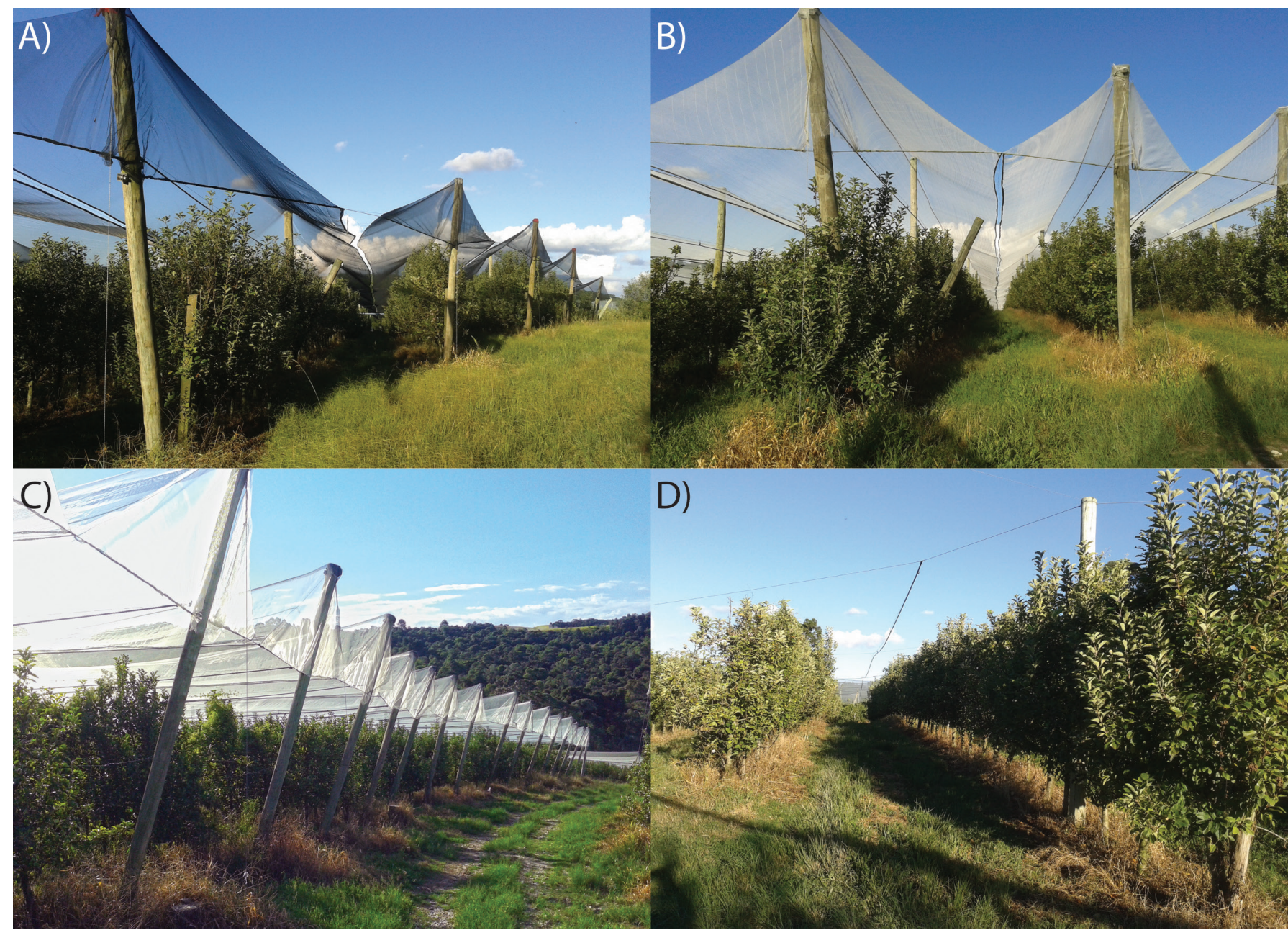

Figure 2. Commercial orchard of 'Eva' apple trees located in Porto Amazonas, PR, Brazil under black (A), crystal/ transparent $(\mathrm{B})$, white $(\mathrm{C})$ protecting nets, and non-covering treatment $(\mathrm{D})$. 


\section{Results and discussion}

Results have shown that the use of protecting nets throughout both crop growing seasons did not generate significant differences on vigor and plant development of apple trees.

The averages obtained from the $2017 / 2018$ and $2018 / 2019$ harvests, were 287.8 and $290 \mathrm{~cm}$ for plant height, 7.52 and $7.45 \mathrm{~cm}$ for trunk diameter, 24.27 and $25.27 \mathrm{~mm}$ for branch diameter, and 101.72 and 109.87 $\mathrm{cm}$ for branch length, respectively.

According to Manja and Aoun (2019), the use of colorful net might be able to be conducive to vegetative growth of apple tree plants due to changes in the orchard microclimate that lead to reductions in leaf and air temperature regime in conjunction with low atmospheric evaporative demand rates, which will advantage net photosynthesis. Nevertheless, Leite et al. (2002) examined the impact of a black anti-hail protecting net on biological responsiveness of Fuji and Gala cultivars in Fraiburgo, State of Santa Catarina, Brazil, throughout five production years and did not come up with significant discrepancies in branch growth between the use or non-use of protecting nets in apple tree commercial orchards. Bastías et al. (2012) found that a reduction of up to $37 \%$ of photosynthetic photon flux density, through the use of color nets, did not affect the growth of shoots and did not limit the allocation of carbohydrates in the plant.

Several factors affect the responses of the apple tree under nets (MUPAMBI et al., 2018), among which stand out the color of the net and changes in the microclimate (IGLESIAS and ALEGRE, 2006; AMARANTE et al., 2009; HUNSCHE et al., 2010; TREDER et al., 2016;), and mainly genetic characteristics (AMARANTE et al., 2011; LORDAN et al., 2018; BOSCO et al., 2020). It is noteworthy that most research on the use of anti-hail net was developed for cultivars with high demands on the number of cold hours ('Gala' and 'Fuji'), with no long-term information for 'Eva', demonstrating the importance of continuing evaluations of this project for at least another five years, since two harvests may not represent enough time to express significant differences in vegetative vigor.
With regards to production aspects no significant differences among treatments were detected for the averages of production $\left(17.20 \mathrm{~kg} \mathrm{plant}^{-1}\right)$, yield $(38,229$ $\left.\mathrm{kg} \mathrm{ha}^{-1}\right)$, and number of fruits per plant, NFP $(152,52)$ during 2017/2018 crop growing season (Table 1), with climatic conditions of clearer days and less rainfall. However, throughout second growing season both crystal and white protecting nets provided the highest significant averages, 237.5 and 190.8 fruits per plant, respectively, as compared to no-screen use (91.0 fruits per plant) and black net treatment (128.1) (Table 1). Regarding the control treatment, there was a strong impact on the final number of fruits per plant in $2018 / 2019$ due to the vulnerability to which the fruits were exposed in this climatic condition such as episodes of rain, hail damage and also wind regimes. The fruits under black net do not receive the damage caused by the impact of rain, but rather, their development is affected by the quantity and quality of the light intercepted by the canopy. A lesser incidence of solar radiation flux density on crop canopy promoted by the black protecting net reduces carbohydrates reserves up to an extend of compromising differentiation of reproductive buds and reducing the number of fruits (AMARANTE et al., 2012).

There were divergent outcomes between seasons on mass and shape of the fruits (Table 2). Throughout the first crop growing season the black net treatment was the only one that significantly impacted both fruit mass $(136.90 \mathrm{~g})$ and diameter $(65.72 \mathrm{~mm})$ compared to control treatment ( $99.76 \mathrm{~g}$ and $58.76 \mathrm{~mm}$, respectively), culminating in better shape responses although production and yield was not affected by the latter treatments adopted. Conversely, during 2018/2019 crop growing season, black net treatment triggered low values of fruit mass $(112.94 \mathrm{~g})$, diameter $(60.80 \mathrm{~mm})$ and height $(62.12 \mathrm{~mm})$. 
Table 1. Production $\left(\mathrm{kg} \mathrm{plant}^{-1}\right)$, yield $\left(\mathrm{kg} \mathrm{ha}^{-1}\right)$ and number of fruits per plant (NFP) for apple trees belonging to the 'Eva' grown under protected environmental and open field conditions throughout the 2017/2018 and 2018/2019 crop growing seasons in Porto Amazonas, PR, Brazil.

\begin{tabular}{lcccccc}
\hline \multicolumn{3}{c}{$2017 / 2018$} & & \multicolumn{3}{c}{$2018 / 2019$} \\
\hline Treatments & $\begin{array}{c}\text { Production } \\
\left(\mathrm{kg} \mathrm{planta}^{-1}\right)^{\mathrm{ns}}\end{array}$ & $\begin{array}{c}\text { Yield } \\
\left(\mathrm{kg} \mathrm{ha}^{-1}\right)^{\mathrm{ns}}\end{array}$ & NFPns & $\begin{array}{c}\text { Production } \\
\left(\mathrm{kg} \mathrm{planta}^{-1}\right)\end{array}$ & $\begin{array}{c}\text { Yield } \\
\left(\mathrm{kg} \mathrm{ha}^{-1}\right)\end{array}$ & NFP \\
\hline Crystal & $17.87 \mathrm{a}$ & $39,702 \mathrm{a}$ & $155.3 \mathrm{a}$ & $24.08 \mathrm{a}$ & $53,512 \mathrm{a}$ & $\begin{array}{c}237.5 \mathrm{a} \\
\text { Black }\end{array}$ \\
White & $17.66 \mathrm{a}$ & $39,231 \mathrm{a}$ & $140.0 \mathrm{a}$ & $14.27 \mathrm{bc}$ & $31,711 \mathrm{bc}$ & $128.1 \mathrm{~b}$ \\
Control & $16.01 \mathrm{a}$ & $35,574 \mathrm{a}$ & $145.7 \mathrm{a}$ & $20.28 \mathrm{ab}$ & $45,068 \mathrm{ab}$ & $190.8 \mathrm{a}$ \\
\hline CV & $17.29 \mathrm{a}$ & $38,409 \mathrm{a}$ & $169.1 \mathrm{a}$ & $10.60 \mathrm{c}$ & $23,562 \mathrm{c}$ & $91.0 \mathrm{~b}$ \\
\hline
\end{tabular}

$\mathrm{CV}$ - Coefficient of Variation (\%). ${ }^{\mathrm{ns}}$ - Not significant. Averages followed by the same small letters in the column do not differ from one another by means of the Tukey Test $(\mathrm{p}<0.05)$.

Table 2. Fruit mass, shape (diameter and height), and fruit firmness for the 'Eva' apple trees grown under protected environmental and open field conditions throughout both 2017/2018 and 2018/2019 crop growing seasons in Porto Amazonas, PR, Brazil.

\begin{tabular}{lcccccccc}
\hline & \multicolumn{4}{c}{$2017 / 2018$} & \multicolumn{3}{c}{$2018 / 2019$} \\
\hline Treatments & $\begin{array}{c}\text { Fruit mass } \\
(\mathrm{g})\end{array}$ & $\begin{array}{c}\text { Fruit diameter Fruit height } \\
(\mathrm{mm})\end{array}$ & $\begin{array}{c}\text { Fruit } \\
(\mathrm{mm})\end{array}$ & $\begin{array}{c}\text { firmness } \\
(\mathrm{N})\end{array}$ & $\begin{array}{c}\text { Fruit mass } \\
(\mathrm{g})\end{array}$ & $\begin{array}{c}\text { Fruit } \\
\text { diameter } \\
(\mathrm{mm})\end{array}$ & $\begin{array}{c}\text { Fruit height } \\
(\mathrm{mm})\end{array}$ & $\begin{array}{c}\text { Fruit } \\
\text { firmness (N) }\end{array}$ \\
\hline Crystal & $115.91 \mathrm{ab}$ & $61.40 \mathrm{~b}$ & $63.40 \mathrm{ab}$ & $44.22 \mathrm{~b}$ & $130.55 \mathrm{~b}$ & $64.84 \mathrm{~b}$ & $65.60 \mathrm{~b}$ & $71,82 \mathrm{a}$ \\
Black & $136.90 \mathrm{a}$ & $65.72 \mathrm{a}$ & $66.68 \mathrm{a}$ & $40.44 \mathrm{~b}$ & $112.94 \mathrm{c}$ & $60.80 \mathrm{~d}$ & $62.12 \mathrm{~d}$ & $75,33 \mathrm{a}$ \\
White & $99.20 \mathrm{~b}$ & $59.32 \mathrm{~b}$ & $59.15 \mathrm{bc}$ & $56.09 \mathrm{a}$ & $145.07 \mathrm{a}$ & $63.80 \mathrm{c}$ & $64.01 \mathrm{c}$ & $76,35 \mathrm{a}$ \\
Control & $99.76 \mathrm{~b}$ & $58.76 \mathrm{~b}$ & $58.40 \mathrm{c}$ & $41.91 \mathrm{~b}$ & $142.72 \mathrm{a}$ & $66.76 \mathrm{a}$ & $66.40 \mathrm{a}$ & $74,62 \mathrm{a}$ \\
\hline CV & 4.88 & 9.20 & 9.23 & 7.08 & 3.43 & 1.18 & 1.37 & 13,74 \\
\hline
\end{tabular}

$\mathrm{CV}$ - Coefficient of Variation (\%). Averages followed by the same small letters in the column do not differ from one another by means of the Tukey Test $(\mathrm{p}<0.05)$.

Cropping system deprived of protecting nets led to a better performance of fruit caliber (diameter and height) throughout the 2018/2019 crop growing season, $99.76 \mathrm{~g}$ and $58.40 \mathrm{~mm}$ respectively. However, fruits subjected to the absence of net did not differ from fruits under white net in terms of mass $(99.20 \mathrm{~g})$, presenting the best results, followed by fruits grown under a crystal net $(115.91 \mathrm{~g})$, both treatments with the best production and productivity averages in this crop growing season.

It is well known that fruit mass, shape (diameter plus height) and color skin are by far very important factors to be borne in mind when it comes to characterize fruit commercial value and also in the view of in natura consumption (TREPTOW et al., 1995). Size and shape might considerably contribute to expedite operations related to fruit processing, such as cuttings, unpeeling, and/ or classification. Fruits subjected to standardization on size and weight ease handling in great quantities, culminating in lesser losses. Oliveira et al. (2014) reported that Eva cultivar particularly evidenced substantial variations in fruit mass ranging from $92.75 \mathrm{~g}$ to $190.85 \mathrm{~g}$, whose values were quite similar to ours.
In the first growing season, with the climatic condition of greater available radiation, clearer, hotter days and with less rainfall (Figure 1) (EPAGRI, 2020), there is a greater mass and height of fruits under a screened orchard, mainly under black net that offers higher shading, represents greater thermal comfort and use of water use, resulting in larger caliber fruits (AOUN and MANJA, 2019). In the following year, with the climate with reversed conditions, the result might be explained by the more pronounced shading of the plants promoted by the black protecting net in conjunction with more frequent cloudy days plus abundant rainfall regimes which, probably, decreased photosynthetically active radiation (PAR) and stomatal opening, as shown in some studies (AMARANTE et al., 2007; MCAUSLAND et al., 2016), thus occurring a reduction in the photosynthetic capacity of the plant and consequently in the production of photoassimilates. 
Amarante et al. (2009) evaluated the effect of white and black nets on biological responses of 'Fuji' apple trees grown in Vacaria, RS, throughout three crop growing seasons and, then, obtained higher values of mean weight of fruits under black protecting net treatment as opposed to white net. Conversely, by taking into consideration studies proposed by Amarante et al. (2011) the use of white net resulted in increases in mean weight of fruits for both Gala and Fuji cultivars. Our results demonstrated that plants covered with white and crystal nets may have production equal to or greater than plants uncovered, as demonstrated by Amarante et al. (2012), while they were also safer as to the risk of damage by hail, excessive wind and sunburn, an advantage over the exposed plants (MANJA and AOUN, 2019).

Throughout the 2017/2018 crop growing season pulp firmness was greater for the fruits exposed to the white net treatment $(56.09 \mathrm{~N})$, as compared to black and crystal nets (40.44 N and $44.22 \mathrm{~N}$, respectively) or the absence of a screen $(41.91 \mathrm{~N})$ (Table 2). On the other hand, during the second crop growing season there was no effect of treatments on pulp firmness, whose average was of $74.53 \mathrm{~N}$.

Softening of the fruits in the face of maturation event is a result of combined actions triggered by enzymes, such as polygalacturonate, cellulate, $\beta$-galactosidases among others, which solubilize compounds present in the cellular wall (pectin, hemicellulose, cellulose) (ZHANG et al., 2010). Oliveira et al. (2014) reported that 'Eva' apple fruits at full-maturity varied from 33.82 to $67.37 \mathrm{~N}$, providing support for the outcomes obtained in our current study during the first crop growing season in particular. Little or no change in firmness under the influence of different colors and shading percentages has also been reported in apple (TREDER et al., 2016), blueberry (LOBOS et al., 2013) and pepper fruits (GOREN et al., 2011).
Chitarra and Chitarra (2005) highlighted that in the face of fruit ripening there was a rise in soluble solids, as well as a drop in titratable acidity linked to consumption of organic acids. Usually literature assumes that apple fruits with ratio $<20$ are considered to be ideal for industry and processing, whereas fruits featured with ratio above 20 are more amenable to in natura consumption. Under the influence of all of treatments throughout both harvests ratio remained above 20, pointing out the potential of 'Eva' apple fruits to be targeted for in natura consumption, regardless of protecting net choice.

Throughout the 2017/2018 crop growing season crystal net referred to the only treatment that promoted significant negative impacts on soluble solids of the fruits, being $11.6 \%$ lower than the average of other treatments, with fruits showing an average of 10.44 ${ }^{\circ}$ Brix. Conversely, during 2018/2019 crop growing season (Table 3) quality parameters of the apple trees was not quite the same, with control treatment providing the highest average of soluble solids (15.12 ${ }^{\circ}$ Brix) followed by the crystal $\left(14.08{ }^{\circ}\right.$ Brix $)$, black (13.84 ${ }^{\circ}$ Brix) and white (13.08 ${ }^{\circ}$ Brix) protecting nets, having noticed, therefore, statistical differences among previous treatments.

Feliciano et al. (2010) demonstrated that apple trees more exposed to incident solar radiation are more prone to reveal higher contents of soluble solids, an observation that might explain why cropping system taking into account non-protecting net in the orchard rendered sweeter fruits. In addition, Iglesias and Alegre (2006) report that fruits under a net later ripen to fruits grown without cover, directly affecting the results of soluble solids in this study, since all treatments were harvested on the same day.

Table 3. Soluble solids (SS), titratable acidity (TA) and Hue angle ( ${ }^{\circ} \mathrm{Hue}$ ) of 'Eva' apple trees grown under protected environmental and open field conditions throughout both 2017/2018 and 2018/2019 crop growing seasons in Porto Amazonas-PR, Brazil.

\begin{tabular}{lcccccc}
\hline \multicolumn{5}{c}{$2017 / 2018$} & & \multicolumn{2}{c}{$2018 / 2019$} & \\
\hline Treatments & $\begin{array}{c}\text { SS } \\
\left({ }^{\circ} \text { Brix }\right)\end{array}$ & $\begin{array}{c}\text { TA } \\
\left(\text { g malic acid } 100 \mathrm{~mL}^{-1}\right)\end{array}$ & ${ }^{\circ} \mathrm{Hue}$ & $\mathrm{SS}\left({ }^{\circ}\right.$ Brix $)$ & $\begin{array}{c}\text { TA } \\
\left(\mathrm{g} \text { malic acid } 100 \mathrm{~mL}^{-1}\right)\end{array}$ & ${ }^{\circ} \mathrm{Hue}$ \\
\hline Crystal & $10.44 \mathrm{~b}$ & $0.40 \mathrm{bc}$ & $32.53 \mathrm{~b}$ & $14.08 \mathrm{~b}$ & $0.29 \mathrm{a}$ & $30.24 \mathrm{ab}$ \\
Black & $11.76 \mathrm{a}$ & $0.42 \mathrm{c}$ & $45.36 \mathrm{a}$ & $13.84 \mathrm{bc}$ & $0.49 \mathrm{c}$ & $34.28 \mathrm{a}$ \\
White & $11.52 \mathrm{a}$ & $0.32 \mathrm{~b}$ & $31.70 \mathrm{~b}$ & $13.08 \mathrm{c}$ & $0.39 \mathrm{~b}$ & $28.12 \mathrm{~b}$ \\
Control & $12.16 \mathrm{a}$ & $0.19 \mathrm{a}$ & $25.05 \mathrm{~b}$ & $15.12 \mathrm{a}$ & $0.47 \mathrm{c}$ & $28.06 \mathrm{~b}$ \\
\hline CV & 9.0 & 37.57 & 12.93 & 8.01 & 16.73 & 23.70 \\
\hline
\end{tabular}

$\mathrm{CV}$ - Coefficient of Variation (\%). Averages followed by the same small letters in the column do not differ from one another by means of the Tukey Test $(\mathrm{p}<0.05)$. 
Oliveira et al. (2014) found values ranging from 9.22 to $13.62{ }^{\circ}$ Brix for the 'Eva' along with titratable

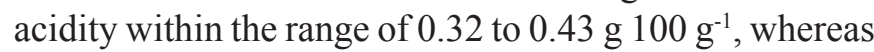
Chagas et al. (2012) obtained similar results reported in the current research expressed by an average of $15.2{ }^{\circ}$ Brix for the same genotype under scrutiny, indicating that the use of protective nets did not affect the organoleptic quality of the fruits for this attribute.

In spite of the fact that black net seems to be conducive to acceptable ratios for in natura consumption, such a treatment resulted in the highest titratable acidity throughout both crop growing seasons (Table 3) with thresholds near or above $0.45 \mathrm{~g}$ of malic acid $100 \mathrm{~mL}^{-1}$ fruit juice, reference value used in order to label fruits as sweet rather than acid (SCHOBINGER et al., 1995). The accumulation of organic acids, such as malic acid, was also observed in tomato (ALDRICH et al., 2010) and grape berry (MARTÍNEZ-LÜSCHER et al., 2017) under black net, and this result can be directly connected to the lower temperature of the canopy due to the increased shadowing. Rienth et al. (2016) observed in grapevine fruits that the decrease in the temperature of the environment favors the accumulation of malic acid due to the expression of the genes involved in respiration of this acid being positive regulated with the increase in temperature.

Our results, which are represented in Table 3 , demonstrated that the use of black protecting net significantly affected Hue angle in comparison to control treatment in both seasons crop, going from 25.05 in the treatment without using nets to 45.36 under black net in $2017 / 18$ and from 28.06 in the control to 34.28 under black net in the 2018/19 season crop, with negative impacts on appearance of the fruits, which had their core more yellowish and less attractive to the consumers. Both white and crystal protecting net treatments did not bring about any significant effect on Hue angle for 'Eva' apple fruits, whose findings obtained herein were in accordance with the outcomes reported by Chagas et al. (2012).

The reddish color of apple peel is mainly due to the biosynthesis and accumulation of anthocyanins and this process is significantly affected by the light composition, as ultraviolet-B (UV-B), light blue, red (R) and far red (FR) radiation, and quantity (BASTÍAS et al., 2012; MUSACCHI and SERRA, 2018). With this, it is noted that fruits more exposed to solar radiation under prevailing weather conditions of clear days mainly might galvanize reddish coloration more rapidly and also more intensively as opposed to fruits protected by anti-hail nets in production fields (LEITE et al., 2002; SOLOMAKHIN et al., 2012; BOSCO et al., 2017; PAVANELLO et al., 2019). Treder et al. (2016) examined the effects of white, gray, black protecting nets along with non-covering treatment on the coloration of 'Sampion' and 'Jonagold' apple fruits and came up with evidences that apple fruits presented a less intense reddish coloration under the influence of gray and black nets, as Pavanello et al. (2019) also evidenced negative effects of black net on apple fruit coloration belonging to Braeburn and Pinova cultivars, agreeing with our results.

The results for peel apple fruits can be justified by the higher shading due to the smaller mesh of the black nets and mainly by the reduced availability of $\mathrm{UV}$ radiation, blue, $\mathrm{R}$ and the $\mathrm{R}: \mathrm{FR}$ ratio in the canopy of the plants under this net, factors that down regulate the expression of genes and transcription factors of the anthocyanin metabolic pathway (UBI et al., 2006; AMARANTE et al., 2007; FENG et al., 2013; LI et al., 2013; AN et al., 2020).

Finally, there was no significant effect of protecting nets on vegetative vigor of the 'Eva' apple trees grown in Porto Amazonas, PR, Brazil, during the two years of study, with possible long-term effect, so this experiment should be continued to monitor possible changes in plant vigor. Production and yield were consistently more expressive under crystal and white protecting nets throughout the second crop growing season mainly. Black net treatment evidenced negative outcomes as to coloration of the fruits in conjunction with titratable acidity, making them less reddish and acid and, therefore, less attractive for the commercial consumption. New treatments should be investigated using the same mesh size for nets, negating any effects of this factor.

\section{Conclusions}

The use of white or crystal anti-hail nets for 'Eva' apple trees is advantageous to guarantee good fruit quality and promote substantial yields in commercial orchards. Conversely, black anti-hail net culminated in negative biological responses concerning coloration of the fruits along with titratable acidity causing them to be less reddish and acidic and, therefore, less enticing for in natura commercial consumption.

\section{Acknowlegments}

The authors are very grateful to the Kitty Apple Fruit Company for the concession of 'Eva' apple tree fruits employed for the conduction of the field trial related to the current research, as well as to peers who work for the Laboratory of Biotechnology Applied to Fruit Science belonging to the State University of Ponta Grossa for the logistical support provided. Special thanks are also devoted to the technician Wilson Padilha for his pivotal assistance along with crop analyses thoroughly made. 


\section{References}

Aldrich, H.T.; Salandanan, K.; Kendall, P.; Bunning, M.; Stonaker, F.; Külen, O.; Stushnoff, C. Cultivar choice provides options for local production of organic and conventionally produced tomatoes with higher quality and antioxidant content. Journal of the Science of Food And Agriculture, London, v.90, n.15, p.2548-2555, 2010.

AMARANTE, C.V.T. do; STEFFENS, C.A.; MOTA, C.S.; SANTOS, H.P. dos. Radiation, photosynthesis, yield, and fruit quality of 'Royal Gala' apples under hail protection nets. Pesquisa Agropecuária Brasileira, Brasília, DF, v.42, n.7, p.925-931, 2007.

AMARANTE, C.V.T. do; STEFFEN S, C.A.; MIQUELOTO, A.; ZANARDI, O.Z.; SANTOS, H.P. dos. Disponibilidade de luz em macieiras 'Fuji' cobertas com telas antigranizo e seus efeitos sobre a fotossíntese, $\mathrm{o}$ rendimento e a qualidade dos frutos. Revista Brasileira de Fruticultura, Jaboticabal, v.31, n.3, p.664-670, 2009.

AMARANTE, C.V.T. do; STEFFENS, C.A.; ARGENTA, L.C. Yield and fruit quality of 'Gala' and 'Fuji' apple trees protected by white anti-hail net. Scientia Horticulturae, Wageningen, v.129, n.1, p.79-85, 2011.

AMARANTE, C.V.T. do; STEFFENS, C.A.; ARGENTA, L.C. Radiation, yield, and fruit quality of 'gala' apples grown under white hail protection nets. Acta Horticulturae, The Hague, n.934, p.1067-1074, 2012.

AMARANTE, C.V.T. do; STANGER, M.C.; COLDEBELLA, M.C.; VILVERT,A. DOS S.; STEFFENS, C.A. Fruit quality and yield of 'Imperial Gala' apple trees protected by anti-hail nets of different colorations in southern Brazil. Acta Horticulturae, The Hague, n.1205, p.897-904, 2018.

AN, J.P.; LIU, Y.J.; ZHANG, X.W; BI, S.Q.; WANG, X.F.; YOU, C.X.; HAO, Y.J. Dynamic regulation of anthocyanin biosynthesis at different light intensities by the BT2-TCP46-MYB1 module in apple. Journal of Experimental Botany, Oxford, v.71, n.10, p.3094-3109, 2020.
AOAC - Association of Official Analytical Chemists. Official methods of analysis of the association of the official analytical chemists. Washington: AOAC, 2007. $1750 \mathrm{p}$.

APARECIDO, L.E. de O.; RICHETTI, J.; SOUZA, P.S. de; JOHANN, J.A. Köppen, Thornthwaite and Camargo climate classifications for climatic zoning in the State of Paraná, Brazil. Ciência e Agrotecnologia, Lavras, v.40, n.4, p.405-417, 2016.

BASTÍAS, R.M; MANFRINI, L.; CORELLI GRAPPADELLI, L. Exploring the potential use of photoselective nets for fruit growth regulation in apple. Chilean Journal of Agricultural Research, Santiago, v.72, n.2, p.224-231, 2012.

BERNARDI, J.; DENARDI, F.; HOFFMANN, A. Cultivares e porta-enxertos. In: NACHTIGALL, G.R. (ed.) Maçã: produção. Bento Gonçalves: Epagri, 2004. p.32-46.

BOSCO, L.C.; BERGAMASCHI, H.; CARDOSO, L.S.; PAULA, V.A.de; MAR O D N, G.A.B.; NACHTIGALL, G.R. Apple production and quality when cultivated under anti-hail cover in Southern Brazil. International Journal of Biometeorology, Heidelberg, v.59, n.7, p.773-782, 2014.

BOSCO, L.C.; BERGAMASCHI, H.; DE PAULA, V.A.; MARODIN, G.A.B.; BRAUNER, P.C. Microclimate alterations caused by agricultural hail net coverage and effects on apple tree yield in subtropical climate of Southern Brazil. Bragantia, Campinas, v.77, n.1, p.181192, 2017.

BOSCO, L.C.; BERGAMASCHI, H.; CARDOSO, L.S.; DE PAULA, V.A.; MARODIN, G.A.B.; BRAUNER, P.C. Solar radiation effects on growth, anatomy, and physiology of apple trees in a temperate climate of Brazil. International Journal of Biometeorology, Heidelberg, v.64, p.1969-1980, 2020.

CALDANA, N.F.S.; SILVA, G.M.F.; MARTELOCIO, A.C.; NITSCHE, P.R., CARAMORI, P. Caracterização das ocorrências de precipitação de granizo e seus impactos socioeconômicos no estado do Paraná. Agrometeoros, Passo Fundo, v.27, n.2, p.1-14, 2019. 
CHAGAS, E.A.; CHAGAS, P.C.; PIO, R.; BETTIOL NETO, J.E.; SANCHES, J.; CARMO, S.A. do; CIA, P.; PASQUAL, M.; CARVALHO, A. dos S. Produção e atributos de qualidade de cultivares de macieira nas condições subtropicais da região Leste paulista. Ciência Rural, Santa Maria, v.42, n.10, p.1764-1769, 2012.

CHITARRA, M.I.F.; CHITARRA, A.B. Pós-colheita de frutas e hortaliças: fisiologia e manuseio. Lavras: UFLA, 2005. 785 p.

CRUZ JUNIOR, A. de O.; AYUB, R.A. Quebra de dormência de gemas de macieira cv.Eva tratadas com cianamida hidrogenada. Revista Brasileira de Fruticultura, Jaboticabal, v.24, n.2, p.576-578, 2002.

EPAGRI - Empresa de Pesquisa Agropecuária e Extensão Rural de Santa Catarina. Banco de dados de variáveis ambientais de Santa Catarina. Florianópolis: Epagri, 2020. 20p.

FAO. FAOSTAT: Statistics database. 2020. Disponível em: http://www.fao.org/faostat/en/\#data. Acesso em: 02 jul. 2019.

FELICIANO, R.P.; ANTUNES, C.; RAMOS, A.; SERRA, A.T.; FIGUEIRA, M.E.; DUARTE, C.M.M.; CARVAlHO, A.; BRONZE, M.R. Characterization of traditional and exotic apple varieties from Portugal. Part 1 - Nutritional, phytochemical and sensory evaluation. Journal of Functional Foods, Binghamton, v.2, n.1, p.35-45, 2010.

FENG, F.; LI, M.; MA, F.; CHENG, L. Phenylpropanoid metabolites and expression of key genes involved in anthocyanin biosynthesis in the shaded peel of apple fruit in response to sun exposure. Plant Physiology And Biochemistry, Amsterdam, v.69, p.54-61, 2013.

GOREN, A.; ALKALIA-TUVIA, S.; PERZELAN, Y.; AHARON, Z.; FALLIK, E. Photoselective shade nets reduce postharvest decay development in pepper fruits. Advances in Horticultural Science, Firenze, v.25, n.1, p.26-31, 2011.

HAUAGGE, R.; TSUNETA, M. Iapar 75 - Eva, Iapar 76 Anabela e Iapar 77 - Carícia - novas cultivares de macieira com baixa necessidade em Frio. Revista Brasileira de Fruticultura, Jaboticabal, v.21, n.3, p.239-242, 1999.
HILGENBERG, T; AYUB, R.A. Evaluation of Brassinosteroids in dormancy break and in growth of branches of Apple Tree (Malus domestica). Ambiência, Guarapuava, v.10, n.2, p.1-6, 2014.

HUNSCHE, M.; BLANK, M.M.; NOGA, G. Does the microclimate under hail nets influence micromorphological characteristics of apple leaves and cuticles? Journal of Plant Physiology, Sttugart, v.167, n.12, p.974-980, 2010.

IGLESIAS, I; ALEGRE, S. The effect of anti-hail nets on fruit protection, radiation, temperature, quality and profitability of 'Mondial Gala' apples. Journal of Applied Horticulture, Lucknow, v.2, n.8, p.91-100, 2006.

LANCASTER, J.E.; LISTER, C.E.; READY, P.F.; TRIGGS, C.M. Influence of pigment composition on skin color in a wide range of fruit and vegetables. Journal of the American Society for Horticultural Science, Alexandria, v.122, n.4, p.594-598, 1997.

LEITE, G.B.; PETRI, J.L.; MONDARDO, M.. Efeito da tela antigranizo em algumas características dos frutos de macieira. Revista Brasileira de Fruticultura, Jaboticabal, v.24, n.3, p.714-716, 2002.

LI,Y.Y.; MAO, K.;ZHAO, C.;ZHAO, X.Y.;ZHANG, R.F.; ZHANG, H.L.; SHU, H.R. HAO, Y.J. Molecular cloning and functional analysis of a blue light receptor gene MdCRY2 from apple (Malus domestica). Plant Cell Reports, Berlin, v.32, n.4, p.555-566, 2013.

LOBOS, G.A.; RETAMALES, J.B.; HANCOCK, J.F.; FLORE, J.A. ROMERO-BRAVO, S.; POZO, A. del. Productivity and fruit quality of Vaccinium corymbosum cv.Elliott under photo-selective shading nets. Scientia Horticulturae, Wageningen, v.153, p.143-149, 2013.

LOPES, P.R.C.; OLIVEIRA, I.V.M.; SILVA-MATOS, R.R.S.; CAVALCANTE, Í.H.L.C. Caracterização fenológica, frutificação efetiva e produção de maçãs 'Eva' em clima semiárido no nordeste brasileiro. Revista Brasileira de Fruticultura, Jaboticabal, v.34, n.4, p.1277$1283,2012$. 
LORDAN, J.; FRANCESCATTO, P.; DOMINGUEZ, L.I.; ROBINSON, T.L. Long-term effects of tree density and tree shape on apple orchard performance, a 20 year study_-Part 1, agronomic analysis. Scientia Horticulturae, Wageningen, v.238, p.303-317, 2018.

MANJA, K; AOUN, M. The use of nets for tree fruit crops and their impact on the production: A review. Scientia Horticulturae, Wageningen, v.246, p. 110-122, 2019.

MARTÍNEZ-LÜSCHER, J.; CHEN, C.C.L.; BRILLANTE, L.; KURTURAL, S.K. Partial solar radiation exclusion with color shade nets reduces the degradation of organic acids and flavonoids of grape berry (Vitis vinifera L.). Journal of Agricultural and Food Chemistry, Washington, v.65, n.49, p.10693-10702, 2017.

MARTINS, J.A.; BRAND, V.S.; FELIX, R.R.; MARTINS, L.D.; FREITAS, E.D.; GONÇALVES, F.L.T.; HALLAK, R.; DIAS, M.A.F.S.; CECIL, D.J. Climatology of destructive hailstorms in Brazil. Atmospheric Research, Amsterdam, v.184, p.126-138, 2016.

MCAUSLAND, L.; VIALET-CHABRAND, S.; DAVEY, P.; BAKER, N.R.; BRENDEL, O.; LAWSON, T. Effects of kinetics of light-induced stomatal responses on photosynthesis and water-use efficiency. The New Phytologist, London, v.4, n.211, p.1209-1220, 2016.

MUPAMBI, G.; ANTHONY, B.; LAYNE, D.R.; MUSACCHI, S.; SERRA, S.; SCH MIDT, T.; KALCSITS, L. The influence of protective netting on tree physiology and fruit quality of apple: A review. Scientia Horticulturae, Wageningen, v.236, p.60-72, mar. 2018.

MUSACCHI, S.; SERRA, S. Apple fruit quality: overview on pre-harvest factors. Scientia Horticulturae, Wageningen, v.234, p.409-430, 2018.

OLIVEIRA, D.L.; ALVARENGA, A.B.; GONÇALVES, E.D.; ABRAHÃO, E.; ZAMBON, C.R.; NORBERTO, P.M. Maçã 'Eva' desponta a produção no estado de Minas Gerais. Informe Agropecuário Epamig, Belo Horizonte, n.141, p.1-4, 2011.
OLIVEIRA, D.L.; ALVARENGA, A.B.; GONÇALVES, E.D.; MALTA, M.R. Qualidade da maçã cv. Eva produzida em duas regiões de Minas Gerais. Brazilian Journal of Food Technology, Campinas, v.17, n.4, p.269-272, 2014.

PAVANELLO, A.P.; ZOTH, M.; AYUB, R.A. ; LOS, K.K. de $\mathrm{S}$. Different methods of thinning influenced by variety and hail nets in apple orchards. Agricultural Research and Technology: Open Access Journal, California, v.3, n.22, p.69-79, 2019.

PORSCH, A.; GANDORFER, M.; BITSCH, V. Strategies to manage hail risk in apple production. Agricultural Finance Review, Bingley, v.78, n.5, p.532-550, 2018.

R CORE TEAM . R: a language and environment for statistical computing. A language and environment for statistical computing. Austria: R Foundation for Statistical Computing. Disponível em: https:/www.R-project.org/. Acesso em: 05 mai. 2020.

RIENTH, M.; TORREGROSA, L.; SARAH, G.; ARDISSON, M.; BRILlOUET, J.M.; ROMIEU, C. Temperature desynchronizes sugar and organic acid metabolism in ripening grapevine fruits and remodels their transcriptome. BMC Plant Biology, v.16, n.1, p.123, 2016 .

SEVER, M.B.; TOJNKO, S.; BREZNIKAR, A.; SKENDROVIĆ BABOJELIĆ, M.; IVANČIČ, A.; SIRK, M.; UNUK, T. The influence of differently colored anti-hail nets and geomorphologic characteristics on microclimatic and light conditions in apple orchards. Journal of Central European Agriculture, Zagreb, v.21, n.2, p.386-397, 2020 .

SCHOBINGER, M. et al. Phenolic compounds in apple juice. Positive and negatives effects. Fruit Processing, Schönborn, v.5, n.6, p.171- 178, 1995.

SOLOMAKHIN, A.; TRUNOV, Y.V.; BLANKE, M.; NOGA, G.J. Environmental changes under hail protective nets with different coloration affect fruit quality. Acta Horticulturae, The Hague, n.932, p.231-237, 2012. 
TREDER, W.; MIKA, A.; BULER, Z.; KLAMBOWSKI, K. Effects of hail nets on orchard light microclimate, apple tree growth, fruiting and fruit quality. Acta Scientiarum Polonorum: Hortorum Cultus, Lublin, v.15, n.3, p.17-27, 2016.

TREPTOW, R. de O.; QUEIROZ, M.; ANTUNES, P. Caracterização físico-química e sensorial de quatro cultivares de maçãs (Malus domestica Borkh.). Revista Brasileira de Agrociência, Pelotas, v.1, n.3, p.179-184, 1995.
UBI, E.; HONDA, C.; BESSHO, H.; KONDO, S.; WADA, M.; KOBAYASHI, S.; MORIGUCHI, T. Expression analysis of anthocyanin biosynthetic genes in apple skin: effect of UV-B and temperature. Plant Science, New York, v.170, n.3, p.571-578, 2006.

ZHANG, L.; CHEN, F.; YANG, H.; SUN, X.; LIU, H.; GONG, X.; JIANG, C.; DING, C. Changes in firmness, pectin content and nanostructure of two crisp peach cultivars after storage. LWT - Food Science and Technology, Amsterdam, v.43, n.1, p.26-32, 2010. 